\title{
DO CAMPUS AO CAMPO: TECENDO A MANTA DA COMUNICAÇÃO NA MEMÓRIA DO PROGRAMA "MOMENTO RURAL"
}

\author{
FROM THE CAMPUS TO THE FIELD: WEAVING THE \\ COMMUNICATION BLANK IN THE MEMORY OF THE \\ PROGRAM "RURAL MOMENT"
}

EL CAMPO DE CAMPUS: TEJIENDO UN PROGRAMA PLAID
COMUNICACIÓN EN LA MEMORIA "MOMENTO RURAL"

RAMOFLY BICALHO

EDNA CHERIAS ${ }^{\mathrm{II}}$

Resumo Este artigo é fruto das pesquisas realizadas no Programa de Pós-Graduação em Educação Agrícola da Universidade Federal Rural do Rio de Janeiro, numa estreita articulação com o desenvolvimento rural, a memória e comunicação, atrelada aos fatores políticos e sociais que influenciam a produção dos saberes. Tem como objetivo central apresentar reflexões acerca dos novos canais de comunicação e suas influências em contextos rurais no Estado de Pernambuco, resgatando a memória do vídeo: Programa Momento Rural. Privilegiamos a metodologia da História Oral e o desenvolvimento dos seguintes tópicos: tecendo a manta da comunicação com os teóricos; entrelaçando os fios da metodologia; fiando com resultados e discussões. Verificamos que nem todo homem do campo é um pequeno produtor, mas se articula de modo diferente com a dinâmica cultural urbana. Palavras-chave: ComunicaÇão; Memória; EducaÇão Agrícola.

Abstract This article is the result of research carried out in the Agricultural Education Post-
graduate Program of the Federal Rural University of Rio de Janeiro, in a close articulation
with rural development, memory and communication, linked to the political and social fac-
tors that influence the production of knowledge. Its main objective is to present reflections

I Universidade Federal Rural do Rio de Janeiro (UFRRJ), Seropédica/RJ - Brasil.

II Universidade Federal Rural de Pernambuco (UFRPE), Recife/PE - Brasil. 
about the new communication channels and their influences in rural contexts in the state of Pernambuco, rescuing the memory of the video: Programa Momento Rural. We privilege the methodology of Oral History and the development of the following topics: weaving the communication blanket with theorists; intertwining the threads of methodology; with results and discussions. We found that not every rural man is a small producer, but he articulates differently with urban cultural dynamics.

Key-words: Communication; Memory; Agricultural Education.

Resumen El presente artículo es fruto de las investigaciones realizadas en el Programa de Postgrado en Educación Agrícola de la Universidad Federal Rural de Río de Janeiro, en una estrecha articulación con el desarrollo rural, la memoria y comunicación, ligada a los factores políticos y sociales que influencian la producción de conocimientos. Tiene como objetivo central presentar reflexiones acerca de los nuevos canales de comunicación y sus influencias en contextos rurales en el estado de Pernambuco, rescatando la memoria del video: Programa Momento Rural. Privilegiamos la metodología de la Historia Oral y el desarrollo de los siguientes tópicos: tejiendo la manta de la comunicación con los teóricos; entrelazando los hilos de la metodología; con resultados y discusiones. Verificamos que no todo hombre del campo es un pequeño productor, pero se articula diferentemente con la dinámica cultural urbana.

Palabras clave: Comunicación; Memoria; Educación Agrícola.

\section{INTRODUÇÃo}

Nossa intenção com este trabalho é divulgar os primeiros resultados da Dissertação de Mestrado em Educação, realizada no PPGEA - Programa de Pós-Graduação em Educação Agrícola da UFRRJ - Universidade Federal Rural do Rio de Janeiro. A presente pesquisa teve como objetivo resgatar a memória do vídeo intitulado Programa "Momento Rural", que surgiu como ação de comunicação da UFRPE, produzido nos anos de 1994 a 1996, com duração de 60 segundos, resultado de um convênio entre a UFRPE - Universidade Federal Rural de Pernambuco, REDE GLOBO NORDESTE e a CENTER VIDEO PRODUÇÕES. Sua exibição ocorria nos intervalos da programação local da TV Globo Nordeste e visava socializar as pesquisas desenvolvidas no âmbito acadêmico da UFRPE, direcionando-as ao público leigo, em linguagem simples, visando sua assimilação.

Visualizamos que particularidades específicas do homem rural geravam interferências na socialização das pesquisas, uma vez que suas expectativas confrontam-se quase sempre com o vazio, por não terem acesso às informações oriundas da UFRPE. Tornou-se evidente que, mesmo inserido na zona rural, nem todo homem é um pequeno produtor, mas se articula de modo diferente com a dinâmica cultural urbana, possui seu modo específico de assimilar, produzir cultura e construir conhecimento.

Percebe-se que ao atuar como artesã de uma manta de conhecimento direcionado à área rural, a UFRPE não alcança plenamente seu objetivo, uma vez que disponibiliza in- 
formações à população no âmbito urbano, acadêmico e científico, deixando de lado uma parcela da sociedade - o homem rural - que continua com pouco acesso às notícias veiculadas em jornais ou mesmo nos programas televisivos direcionados à zona rural, e, por conseguinte, permanece à margem desse conhecimento. Evidencia-se a necessidade de direcionar também suas pesquisas ao homem rural, especificamente no Estado de Pernambuco, adaptando o texto científico à linguagem popular a fim de facilitar sua compreensão.

Tomando o vídeo "Momento Rural" como ponto de partida, focamos a comunicação como característica mais importante deste estudo, onde, para que uma transmissão obtenha sucesso, é necessário adotar alguns cuidados, por exemplo, que o comunicador conheça os pressupostos que envolvem os meios de comunicação e adapte a linguagem de forma adequada. Outra questão que se coloca é o acervo do conhecimento cultural vivenciado pelo receptor, para que se possa direcionar a mensagem de forma que a mesma surta os efeitos comunicacionais desejados. Como relevância social desta pesquisa, destacamos a comunicação como um processo inerente ao ser humano, onde, por meio da linguagem e dos símbolos, ocorre a troca de experiências e vivências, num processo de realimentação constante, enquanto ser social. Sua importância reside no fato de que poderá se constituir como estratégias de comunicação, socializando o conhecimento produzido na UFRPE, direcionado ao homem rural, como receptores externos de suas políticas.

Como estado da arte, destacamos que a comunicação tem o poder de transformar a vida das pessoas - ou seja, o conhecimento traz mudanças de vida. Igualmente, os canais de comunicação devem ser observados quando desejamos alcançar um público específico e os conteúdos da mensagem precisam ser direcionados ao público-alvo, sendo apresentados de forma simples e clara para que possam ser reapropriados. A comunicação e a educação devem dialogar com as demandas cotidianas da sociedade. Um público específico tem seu repertório cultural exclusivo e, portanto, receberá a informação segundo seu conjunto de particularidades. Deverá agir de acordo com esses filtros culturais, visando minimizar os choques de comunicação. Essas evidências nos motivaram a realizar esta pesquisa com o tema da comunicação no contexto rural, utilizando como recorte, o resgate do Programa Momento Rural, a partir de sua trajetória, memória e percepção do grupo coordenador dessa ação e da comunidade emitente e destinatária do mesmo. Buscamos a percepção do nosso público-alvo visando detectar a forma eficaz de comunicar, acompanhar, corrigir ou melhorar essa ação de comunicação.

Como uma manta de vários fios, a comunicação se traduz no intercâmbio de informações entre sujeitos. E como manta costuramos esses fios, buscando o conceito de metáforas, que se trata da aproximação de dois seres ou coisas, passando as características de um para o outro. A comunicação pode ser percebida como o resultado do entrelaçamento de fios, por meio da urdidura e a trama, num movimento vertical e horizontal do pente, sucessivamente de um lado para o outro. Tal procedimento se assemelha ao processo de interações comunicacionais, que vão sendo alimentados por novas informações, que como fios, se desenrolam, costuram, escapam, são reapropriados e constroem novos significados, trazendo a linguagem para o campo visual. 
Assim, entrelaçamos os fios da memória no intuito de resgatar a construção e veiculação do programa Momento Rural, tendo como fio condutor a comunicação, uma vez que se traduz em ação de comunicação, agregando a educação em contexto rural como forma de construção de conhecimento direcionado ao homem rural. Utilizamos como metodologia a História Oral, potencializando a oralidade, capturando a voz e os silêncios, enfatizando a importância do que está sendo dito e não dito (BORDENAVE, 1998). No tecer desses fios, a comunicação oriunda da UFRPE deve atuar como uma ação social, repensando as próprias formas de construção do conhecimento. Ter consciência dessa imagem social da UFRPE faz parte da ação corajosa de quem buscou uma comunicação plena, mais efetiva, mais completa. Somos percebidos pela maneira de comunicar no que diz respeito às formações sociais, profissionais e culturais, libertando e proporcionando liberdade no ato de expressão, transformando pensamentos pela arte de se expressar.

\section{Desenvolvimento}

\section{Tecendo a manta da comunicação com os teóricos}

Com um olhar contemporâneo, alcançamos que o Programa Momento Rural foi exemplo de ousadia e inovação, rico em informações e imagens, num tempo e espaço delimitados e pretendia levar ao homem rural, seu público-alvo, possibilidades para suas demandas por meio da comunicação. A comunicação caracteriza-se em uma informação. $\mathrm{O}$ seu uso tem sido utilizado no domínio das ciências sociais, em particular, daquela em que a memória constitui, ao mesmo tempo, o material e o objeto da história. Coadunando com essa proposta, trazemos a afirmação de Le Goff (1998, p. 205):

\footnotetext{
Nas sociedades, a distinção do presente e do passado (e do futuro) implica essa escalada na memória e essa libertação do presente que pressupõem a educação e, para além disso, a instituição de uma memória coletiva, a par da memória individual.
}

Trazer a história do Programa Momento Rural como objeto de perspectiva ao homem do campo encontra fundamentação nesse teórico que declara "as sociedades ditas tradicionais, especialmente as camponesas, não são tão estáticas como se julga". As sociedades constituídas recebem a inovação "sob a forma de um regresso ao passado: é a ideia-força das "renascenças" (LE GOFF, 1990, p. 213). Entrelaçamos os fios da educação, por intermédio de ações como o Programa Momento Rural, como canal de comunicação e veículo de conhecimento, sob a perspectiva de Freire (2013), que traz o modelo de educação dialógica, potencializando o poder criador do homem, alimentando sua criticidade, transformando o mundo, educando para a prática de liberdade. A universidade deve ecoar Paulo Freire quando afirma que "solidarizar-se com os oprimidos é algo mais que prestar assistência a trinta ou a cem, mantendo-os atados, contudo, à mesma condição de dependentes”. A 
solidariedade é "assumir a situação de com quem se solidarizou", é "com eles lutar para transformação da realidade" (FREIRE, 2005, p. 36). Tecemos com Arroyo que percebe o importante papel do educador, em tempos de mudanças, como "tempo propício e oportuno para repensar a educação", diante das transformações que o campo no Brasil está vivendo. Como educadores é primordial entender que

(...) temos de ter sensibilidade para essa dinâmica social, educativa e cultural, e perguntar-nos que novos sujeitos estão se constituindo, formando, que crianças, jovens, adultos (...) que lideranças, que relações sociais de trabalho, de propriedade, que valores (...) nosso olhar não pode ser apenas a escola (...) temos de olhar e entender como nesse movimento social vêm se formando e educando (...) (ARROYO, 1999, p. 14).

Nessa manta, portanto, entrelaçando os fios da comunicação com a Memória e a Educação, por meio da metodologia da História Oral, apreendendo um campo inesgotável nas entrelinhas do social, resgatando a memória do Programa Momento Rural, que buscava uma narração contextualizada, focando raízes e culturas do homem rural, trabalhando a questão do moderno e o tradicional, o regional e o globalizado, atuando como ação de transformação de identidades em contextos rurais, desprezando o alienante e priorizando a informação conscientizada.

\section{Entrelaçando os fios da metodologia}

Para que os fios dessa manta da comunicação fossem amarrados de maneira uniforme e coerente, buscamos a metodologia da História Oral, como método específico das ciências sociais, entrelaçamos a vivência do passado e presente com expectativa de determinar o futuro. Alistair Thomson, professor de História da School of Philosophical, explica que a História Oral ganhou força a partir da década de 1960, quando surgiram métodos de entrevista e análise utilizando fontes orais. Nesse sentido, Philippe Joutard alega que a história oral não está mais em suas primícias, "chegou já à primavera e é cada vez mais reconhecida e compreendida nos círculos acadêmicos mais tradicionais. Os que contestam a fonte oral travam combates ultrapassados" (JOUTARD, 2000, p. 32).

Alessandro (PORTELLI, 2000) afirma que, por seu caráter qualitativo, a História Oral visa resgatar por meio de suas memórias a reconstrução do passado dos sujeitos e se impõe como uma metodologia eficiente que aborda a compreensão dos fatos em tempo presente, desvendando sonhos e anseios das pessoas que presenciaram acontecimentos em sua época. Fontes orais "contam-nos o lado psicológico emocional do povo, quanto não só ao que fez, mas o que queria fazer, o que acreditava estar fazendo e o que agora pensa que fez" (PORTELLI, 1997, p. 31).

Alberti (2005) é mais enfático e fornece a lógica da utilização da história oral como metodologia, alegando que uma de suas qualidades reside no fato de apenas ser utilizada em pesquisas de temas contemporâneos, ocorrências recentes, na medida em que a memó- 
ria possa alcançar, entrevistando pessoas que viveram ou testemunharam os acontecimentos. Essa metodologia se traduz como um meio de buscar o conhecimento de determinado tema, ouvindo pessoas que têm algo a dizer sobre a questão e apreender as versões fornecidas pelos entrevistados acerca do objeto de análise. Paul Richard Thompson professa que "historiadores orais podem buscar a evidência de que precisam, ir procurá-la e obtê-la", proporcionando uma ruptura da fronteira entre o acadêmico e o mundo, entre o profissional e o público comum, em detrimento dos "velhos catálogos bibliográficos" (THOMPSON, 1998, p. 25).

Surgem com esses teóricos novos meios e estímulos para essa prática metodológica. Nesse sentido, optamos pela abordagem da História Oral, por meio de fontes orais, objetivando resgatar a história a partir do conhecimento prévio do Programa Momento Rural, agregando novos olhares por intermédio da memória daqueles que participaram de sua construção e ou veiculação, avaliando o que as pessoas pensam ou acreditam que os fatos sejam, e, a partir daí descobrir, por meio das definições individuais, planos de ação de comunicação adequados a uma realidade contextualizada. Para Portelli (2000, p. 66), essa metodologia tem a ver "com toda a discussão de História versus Memória".

Essencialmente, disseram-nos que uma memória individual é ideológica, mitológica, não confiável - razões pelas quais, aliás, eu a aprecio - mas isto é a memória. A história, no entanto, é propriedade de instituições e de historiadores profissionais.

Pautados nas afirmações dos autores citados, a utilização da História Oral permitiu acrescentar uma "dimensão viva", colhendo novas perspectivas à história, permitindo construir um discurso de interpretação histórica com riqueza e complexidade. Nas ciências sociais quando o foco da história recai apenas sobre a história intelectual, perde sua essência, que deve basear-se em tudo aquilo que é considerado conhecimento na sociedade. Acolhendo esses fios no universo das investigações científicas, em geral utilizam-se vários métodos e técnicas quanto forem necessários ou apropriados para determinado caso. Assim empregamos dois instrumentos metodológicos para a coleta de dados, a entrevista temática, aplicada a 3 (três) sujeitos e elaborada em bloco, e a entrevista com roteiro geral, com 12 participantes, colhendo depoimentos orais, buscando subjetividades, distinguindo gênero, idade, estado civil, formação acadêmica e profissão como um diferencial entre as categorias. Utilizamos esses dados no intento de compreender melhor o relato das experiências interligadas com a biografia. Salientamos que a escolha dos dois tipos de instrumentos de coleta de dados justificou-se pela variedade sociocultural do universo que pretendíamos estudar e os objetivos distintos da pesquisa.

As entrevistas temáticas se transformarão em documentos, catalogados e entregues às Bibliotecas Centrais da UFRRJ e a UFRPE, instituições envolvidas na pesquisa, sendo incorporados ao conjunto de fontes para novas pesquisas por suas categorias de análise: reconhecimento, identidade, valorização de heranças familiares, vida cultural, memória, relações pessoais e sociais, formação, relação com a comunicação, educação e contextos 
relacionados ao Programa Momento Rural, onde suas histórias, repletas de memória possam ser conhecidas e reconhecidas, situando assim "quem fala" e "por que" optou pela trajetória que o levou a participar do tema em questão. No tecer de muitos fios, o contato com os teóricos nos mostrou uma riqueza de informações referentes à metodologia da história oral, no entanto, apresentou-se como essencial para a análise dos resultados a escolha da construção social da realidade com Berger \& Luckman (2008) e Bordenave (1998), que nos trouxeram os pensamentos e ações, concepções e ideias, utilizando a natureza intrínseca da oralidade, buscando a experiência de vidas das pessoas envolvidas e não envolvidas diretamente na temática histórica do Programa Momento Rural.

\section{FiANDO COM OS RESUltados E DISCUSSÕES}

De formatos, cores e texturas diferentes, inúmeros são os fios que tecem a manta de possibilidades na arte de comunicar. Comunicar é um fenômeno essencial do ser humano, estando presente no processo do pensamento, ideias e ações. Por meio da comunicação, opera-se a troca de vivências, experiências e de sentimentos entre o homem e seus semelhantes, numa realimentação permanente onde conhecem e partilham códigos e significados comuns, por intermédio da linguagem. O processo da comunicação pela linguagem é uma particularidade essencialmente humana, que permite forjar a consciência, onde o homem é capaz de distanciar-se de si mesmo, "exteriorização", em um processo de reflexão, a "objetivação" e retorna à sua realidade, a "interiorização", na qual o mundo é reintroduzido na consciência no curso da sua socialização. A construção social da realidade está ancorada nesse tripé.

Essa existência humana, por meio da linguagem, torna o mundo um conjunto ordenado e coerente de tudo aquilo que tem nome. Por intermédio da linguagem, o homem cria e significa o mundo, emprestando sentido a todos os conceitos e construções que permeiam as atividades humanas. Essa construção traz em seu bojo o conhecimento prático da vida cotidiana, apreendido pela linguagem, onde o homem atua de forma "desembaraçada" e o habilita a viver o seu cotidiano de maneira prática e eficiente. Para se comunicar, os seres humanos utilizam um sistema simbólico, complexo e, cada processo de comunicação empregado corresponde às necessidades específicas de cada grupo cultural e se encontra adaptado aos vários contextos. $\mathrm{O}$ ser humano está permanentemente a se comunicar, mesmo que não tenha consciência disso. Sua maneira de vestir, o modo de atuar, tom de voz, um gesto, um sorriso, por meio da linguagem verbal ou não verbal estão sempre a transmitir as mais variadas mensagens. Esses fenômenos da comunicação estão presentes à sua volta. A comunicação é, pois, um processo ininterrupto e permanente.

Esse processo nos mostra que, por intermédio da percepção que o homem tem do meio ambiente, e ancorado em seus repertórios, ou seja, seu acervo de conhecimento, ele interpreta o mundo e, a partir daí, transforma-o em novos significados. Em interação com outros homens surge o diálogo, por meio de mensagens, ocorrendo a convergência de significados. Nesse processo de comunicação, insere-se a intenção, que se apresenta como "básica", onde 
se espera que o outro selecione, compreenda, aceite, e aplique a mensagem recebida (BORDENAVE, 1998). Apreendemos que com a chegada da energia elétrica ampliou-se os canais de comunicação e o homem rural foi inserido nas novas tecnologias e mídias globais. Essas novas tecnologias transformaram o homem rural, confirmando o que assevera Arroyo (1999, p. 14) "o campo está vivo, há mais vida no campo que no asfalto das cidades".

A eletrização rural traz no bojo de suas consequências o acesso aos canais de comunicação, caracterizando-se também como desenvolvimento socioeconômico, trazendo a cidadania, vinculando a comunicação com educação por meio das tecnologias, como a televisão, rádio e internet que encurtam as distâncias e alimentam as mudanças sociais. Conforme entrevista realizada com Afonso, a energia elétrica impulsionou a construção do conhecimento: “(...) então ... o que ajudou muito, foi a iluminação, a iluminação rural... a iluminação deu um salto e tanto... você imagina morar num lugar que não tem luz... sem luz você não faz nada ... hoje isso ajudou demais... você não pode planejar sua vida, você não tem perspectiva de crescer, nada, entende? ... tudo que está relacionado ao seu bem estar e de trabalho também... isso melhorou muito". Trabalhar as mudanças sociais por meio dos fios da comunicação é trabalhar também a relação de consumo com esse público receptor, que cria sua identidade a partir de mensagens recebidas dos meios de comunicação. Nessa perspectiva, as mensagens do Programa Momento Rural tinham a intenção de decodificar as pesquisas em linguagem simples, destinada ao público leigo, apostando no processo de comunicação que consiste na reciprocidade, onde não há sujeitos passivos. A comunicação deve caracterizar-se no diálogo crítico sendo, portanto, comunicativo e participativo.

Nas construções da realidade social dos homens rurais apresenta-se também a evidência de atitudes e condutas, valores gerais que se têm como verdadeiros na sociedade, que pode ser percebido por meio da História Oral, apreendido em contextos, ou seja, o local e a classe social de onde emanam as informações com mais de um ponto de vista sobre a mesma questão, residindo nessa institucionalização a previsibilidade de ações e intenções. Essa evidência nos traz a distribuição social do conhecimento que diferencia a realidade por graus de aproximação e familiaridade, assim, os homens rurais se percebem com seu acervo de conhecimento específico, onde o "sei que fazer" se apresenta de forma satisfatória para suas atividades da vida cotidiana, integradas com o seu mundo do trabalho, apreendidas como reflexos das ideias da cultura local. Reforçando essa questão acreditamos que "a validade do acervo do conhecimento é suposta certa por mim e pelos outros até nova ordem, isto é, até surgir um problema que não pode ser resolvido nos termos por ela oferecidos" (BERGER \& LUCKMANN, 2008, p. 65).

O Programa Momento Rural foi apreendido de diversas formas, o que colabora com a afirmação de que os significados "são concebidos com "conhecimento" e transmitidos como tais. Uma parte deste é julgada para todos, enquanto outra só interessa a certos tipos. Alguns são designados como transmissores, outros como receptores deste "conhecimento" (BERGER \& LUCKMANN, 2008, p. 99). Nessa percepção, apresentamos a realidade apreendida pelos docentes e técnicos, como sujeitos envolvidos com o "conhecimento" oriundo de uma instituição educacional, que reconhecem o valor de um canal de comu- 
nicação voltado para a mudança social em contexto especificamente rural, onde Afonso "mostra que existe uma instituição que está fazendo alguma coisa como rural, a essência disso... se é um fungo, se mexe com cana, tudo bem... a questão é que ela faz realmente alguma atividade para servir ao produtor, isso é fato!"

Nesse sentido, o acervo do conhecimento se propõe para os diversos papéis que representamos na vida, seja como educadores e comunicadores do conhecimento ou como homens rurais, dotados de um acervo de conhecimento conveniente para o seu "aqui e agora". Foi necessário que uma instituição de ensino problematizasse o cotidiano desses homens, receptores finais de suas políticas para, a partir daí, construírem, em diálogo e sintonia, as soluções adequadas. Nesse viés da contribuição social, o Programa Momento Rural vem atender o Artigo 221, no Inciso III da Constituição Federal que estabelece a obrigatoriedade da regionalização da comunicação, onde as redes de televisão devem reservar um espaço de tempo para as questões locais e regionais, obviamente se tratando de temas de interesse econômico e social, como pondera Ataulfo:

O Momento Rural era uma inserção de uma Televisão de grande penetração. Então ela estava mostrando o Momento Rural, mostrando a peculiaridade da região onde uma Universidade Pública Federal tinha uma inserção, não só de ensino mas de investir e participar do desenvolvimento das Regiões. Ela estava presente, com a sociedade, a desenvolver a Região, é isso que o Momento Rural mostrava.

No acervo do conhecimento, essa acumulação é transmitida de uma geração a outra como um processo de liquidez que se molda à vida cotidiana e se apresenta útil ao indivíduo na medida em que é comum do mundo. Vivemos num mundo constituído de senso comum, onde contamos com conhecimentos específicos, permitindo ao homem sua localização na sociedade.

Assim, apresenta-se como participação democrática o processo de comunicação humana, envolvendo o acervo do conhecimento, por meio da linguagem, onde o mundo é apreendido em confronto com o repertório das experiências individuais, suas crenças, valores e atitudes. Nessa perspectiva, podemos entender que quanto maior for o seu repertório de linguagem, tanto maior será o mundo percebido, num constante movimento de realimentação de conhecimento que se incorpora à sua linguagem e compreensão desse mundo. Para Berger \& Luckmann (2008), a realidade por excelência da vida cotidiana está organizada em torno do "aqui" do corpo e do "agora" do presente, sendo o foco da atenção. Porém, não se esgota nesses imediatos, mas transcende fenômenos que não estão aqui e agora, mas se encontram em diferentes graus de aproximação e distância, espaço e tempo.

Diante das mudanças sociais, econômicas e estruturais surgidas, seja pela educação, comunicação de massa ou mesmo por meio de estradas que encurtam as distâncias, como formas de interagir com o mundo, os jovens não mais se sujeitam ao trabalho pesado do "roçado". ${ }^{1}$ Essa percepção fica evidente na fala do agricultor Izidoro:

1 Terra onde se roça mato; terra cheia de mato. 
Esse negóço de... De se aposentá. O avô é aposentado, a avó recebe... aí dá um dinheirin pro neto... ele im vez de ele ir trabaiá, ele diz: ah, minha avó me fornece. Né? Eu acho que é isso aí, né? Até precisa de gente que trabaie... É! Gente tem! Aí eu num sei nem... nem dizer. Esse bolsa famía... essa bolsa famía ajuda muito... pra o pobre que num tinha condiçõises, recebe aquele bolsa famía, eu num vou dizer nem falá contra... Eu acho que... (...) (balança a cabeça negativamente) Maises pior se num fosse, num é? É! Aí o causo sabe o que é? O causo é esse... Lá na cidade, um casá que pensa, arruma dois fio parou! E depois disso aí... ói... arrumá fio pra pegá aquele... (risos) Quem tem deizis fio quanto eles num derruba, né? (Risos).

Nesse sentido, os programas sociais cumprem seus papéis, ou seja, por meio da educação e assistência social, fornecem condições para que os jovens possam buscar nas cidades próximas o Ensino Médio, agregando novos valores e perspectivas de vida. Reconhecemos também a relevância dos canais de comunicação disponíveis nas comunidades rurais fornecendo elementos que contribuem para o desejo e desafio na vida desses jovens, proporcionando novas perspectivas e horizontes, fomentando novas configurações nas maneiras de se perceberem, implicando na transformação de vida percebidas a cada história, moldando o "rumo e a direção da mudança social mais ampla" (THOMPSON, 1998, p. 329-330). O desenvolvimento econômico e social chegou em algumas áreas rurais, impulsionado pelas intervenções dos programas sociais, porém, a cultura permanece interiorana, com sensação de bem-estar e familiaridade entre os sujeitos, que não querem a vida das grandes cidades e seus percalços veiculados pelos mesmos canais de comunicação. Berger \& Luckmann (2008, p. 107) afirmam que o corpo do conhecimento "está diretamente ou indiretamente adequado ao seu papel. O que implica uma distribuição social do conhecimento, que acha-se estruturado em termos do que é geralmente relevante e do que é somente relevante para papeis particulares".

Essa percepção torna-se relevante, uma vez que esses jovens rurais absorvem dos canais de comunicação aquilo que lhes convém como projeto de vida e, mesmo sem um letramento digital adequado para estarem em contato com as mídias virtuais, demonstram apreender as informações que se apresentam adequadas aos seus anseios de uma mudança social. Por intermédio da cultura compartilhada e construída entre seus iguais, os homens atribuem significados ao que lhes chega de fora via meios de comunicação de massas e isso se percebe nas formas de organização para o trabalho, o lazer, o estudo, em movimentos sociais, no consumo, trazendo anseios peculiares e de pertencimento (SILVA, 1997).

Observa-se outro fator interessante, o uso de mão de obra especializada em serviços municipais, como enfermeiras, dentistas, assistentes sociais, entre outros, ocupados por jovens da localidade, que retornam com formação acadêmica, e recebem remuneração condizente ao mercado. Muitos desses jovens encontram-se hoje empregados também em indústrias dos derivados de leite, que se instalaram nas redondezas atraídos pela logística e mão de obra qualificada.

A comunicação pode ser apreendida como arte no sentido de contribuir na busca de elementos de apreensão da percepção do homem, por meio das mensagens veiculadas em 
sintonia com a cultura local e seus padrões de linguagem e tecnologia no sentido do desenvolvimento de técnicas nos últimos 20 anos, iniciada com a popularização dos rádios transmissores, chegando aos modernos aparelhos celulares.

A comunicação pode utilizar, em sua arte de comunicar, a evolução tecnológica para conquistar espaços de apropriação de conhecimento, que atendem às demandas de todas as sociedades, respeitando suas culturas e seus acervos de saberes, legitimando suas práticas cotidianas, seja por meio da televisão ou rádio, que se encontram postos na vida cotidiana das pessoas. Cabe ressaltar que a televisão não se apresenta mais como canal de comunicação por excelência nas comunidades rurais. A população em idade laboral mais avançada utiliza esse meio de comunicação apenas para entretenimento e busca informações para o seu cotidiano em programações específicas de rádio, agregado às funções de celulares de última geração.

Com esse olhar, insere-se o rádio que ainda se apresenta como canal de comunicação de massa de extrema importância para o contexto rural. Existem programas que promovem uma ligação intersubjetiva com a comunidade local, estimulando os ouvintes a enviarem suas perguntas relacionadas aos problemas do seu cotidiano. Isso fica evidente na declaração que "quando uma comunidade tem problemas crônicos, tendem a pensar que são parte da própria vida". No entanto, quando esses problemas são discutidos por intermédio de um canal de comunicação acessível a todos, esses meios atuam como "espelhos" onde se enxergam sob uma nova luz, gerando autoconscientização. A conscientização grupal para diagnóstico e solução de problema não se apresenta como fato novo, residindo a novidade em utilizar os meios de comunicação de massa para favorecer essa atitude (BORDENAVE, 1998, p. 95-96).

Assim o rádio na construção social da realidade possui a representação de um canal de comunicação de massa de longo alcance, atendendo às classes sociais distintas e mais especificamente às comunidades rurais, que em meio às novas tecnologias, conservam o hábito de ouvir a programação. Thompson (1998, p. 300) descreve em síntese a articulação entre a tecnologia e a arte de comunicar:

\footnotetext{
O rádio também tem desenvolvido uma arte muito especial de transmitir cenas e mensagens sonoramente. (...) eliminam hesitações e pausas, como também ganham maior realce por uma nova disposição das palavras e podem introduzir ruídos de fundo. (...) Os recursos técnicos do rádio, pode, por certo, tornar mais breves e mais eficazes as citações.
}

Isso vem sugerir que o rádio pode se apresentar como ferramenta alternativa da construção do conhecimento, buscando os meios tradicionais do povo, numa orientação a redescobrir a cultura, abrindo espaços e valorizando as práticas do cotidiano do homem rural num processo de integração dos sujeitos, criando uma relação de permuta de temas próprios, enriquecendo por meio de mensagens os múltiplos saberes. Essa percepção fica clara na fala do entrevistado Afonso que cita um programa de rádio com conteúdo de excelência direcionado para o pequeno produtor rural, apresentado às 5 horas, que utiliza um vocabulário específico: 
(...) E ele traz um gravador: bom dia ouvinte do arraial do Gláucio Costa, aqui quem tá falando é (omitido), atendendo a pergunta de papiloma, o que deve ser feito ... e aí eu falo. $\mathrm{O}$ índice de audiência dele ... é um dos programas mais ouvido hoje... sem sombra de dúvida, nesse horário! Ele grava seis dúvidas e chega aqui grava...(...) porque o rádio ainda tem... 'eh' ... poder de penetração muito grande... espetacular... esse é o programa...de comunicação de massa, esse é programa!

Nessa perspectiva do uso educacional do rádio, destacamos a participação interativa do público-alvo rural nessa ação, como processo de realimentação, quando constrói conjuntamente o conhecimento. Bordenave (1998) justifica que não há razão para não incluir os grandes meios de comunicação como rádio, TV e jornal, desde que estes modifiquem sua estrutura interna e sua metodologia de programação, na função social de levar conhecimento, dentro de uma estratégia comunicacional, abrindo espaço para a participação da população. Entende-se como participação popular as relações de troca de informações por intermédio de mensagens, onde esses canais podem ser considerados agentes do diálogo com a sociedade, onde os meios apresentam uma ideologia própria, assumindo um papel de construtor da realidade.

A comunicação humana vista como linguagem e habilidade cognitiva é tão importante quanto o autocontrole do corpo e das emoções e capacita o homem no desenvolvimento de outras habilidades, permitindo agregar ainda conhecimentos intuitivos, por exemplo, segurança e autoconfiança. Cada receptor ou interlocutor troca informações ancoradas em seu repertório cultural, sua formação educacional, vivências e experiências, emoções e percepções, que também é conhecido como "bagagem". Uma boa comunicação deve envolver objetivos, adequação de linguagem e criação de uma interação pautada no respeito ao acervo do conhecimento do interlocutor, dando-lhe oportunidade de contrapor e ouvir o que o outro tem a dizer. Comunicar é estar em comunhão com o ambiente onde há convivência entre pessoas. Toda mensagem é formada por estruturas organizadas de signos contendo intenção, conteúdo e sentido. Como produção do homem, as mensagens e os signos encontram-se presentes na construção social da realidade por meio da linguagem e da consciência.

A transmissão de uma mensagem clara e objetiva envolve diversos fatores, um deles é conhecer a particularidade dos ouvintes, para que estes possam elaborar e reapropriar essa comunicação também de forma eficiente. O conhecimento construído não é estático ou definitivo, assim, nessa fase de análise dos dados percebemos que inúmeros assuntos foram abordados, porém, cabe destacar os de maior relevância para o tema, num processo de interpretação que exige flexibilidade e imaginação no tratamento dos assuntos de maior interesse para a pesquisa (THOMPSON, 1998, p. 320-321).

Para entendermos a comunicação de massa, foi necessário apreender o surgimento da massa. Com as classes populares, definida como agrupamento de indivíduos que apresentam características similares, nasceu a massa, que desarticulou as formas tradicionais de participação e representação da sociedade, afetando a vida, o pensamento e a própria 
fisionomia da cidade. Essa massificação afetou a todos, principalmente o homem rural. Ele teve que aprender, entre outros aspectos, a inserir-se nas mídias globais.

Para a massa, houve mais ganhos que perdas, pois nasceu também a possibilidade de ascensão social, por meio de bens e serviços que até então tinham sido privilégio de poucos. Foi necessário entender o surgimento da massa para analisar então a comunicação de massa. Assim, a comunicação de massa é entendida como a disseminação de informações por intermédio de jornais, televisão, rádio, cinema e agora a internet, os quais se reúnem em um sistema denominado mídia, tendo como característica principal, alcançar uma grande quantidade de sujeitos, individuais e coletivos, ao mesmo tempo.

Coube-nos apreender a comunicação como ação social, que se firma no direito do cidadão não apenas ter a informação. Nesse viés de comunicação social, nasce também a orientação para que os meios de comunicação de massa se comprometam com os efeitos das mensagens sobre a grande massa. Nesse contexto, trazemos a questão dos conteúdos como direito do cidadão a informações de qualidade. Nesse sentido, foi necessário refletir as grandes questões da comunicação de qualidade. O conhecimento pode gerar organização de informações, que desarticulada torna-se mutilada. Segundo anais da INTERCOM (2001), "a interatividade e a velocidade de informações que transitam nas redes virtuais vão ao encontro das demandas de um ambiente extremamente competitivo, no qual as organizações e suas equipes de trabalho são imperativamente convidadas a se desenvolverem, sob pena de caírem em obsolescência e até irem a óbito". Os atos de comunicação e os recursos tecnológicos devem contribuir para a melhoria do padrão de vida e bem-estar dessa população. Em tempos de multimídias, cabe às instituições educacionais pensar o ser humano como ser complexo, devendo primeiramente ensiná-lo a ser crítico na escolha dos conteúdos.

Para os conteúdos das mensagens veiculadas pelos canais de comunicação de massa, são inúmeros os críticos da televisão, que denunciam a decadência cultural que ela representa e acarreta. Aos poucos, colocam-se propostas de uma elevação cultural desse meio. Diante do exposto, fica claro que os meios de comunicação de massa podem ser usados tanto para fornecer informações úteis e importantes para a sociedade, como para alienar, determinando um modo de pensar e induzindo comportamentos.

Nesse sentido, sugere-se uma leitura crítica dos meios de comunicação, propondo potencializar seus efeitos, uma vez que seu acesso pode se apresentar de forma positiva, estendendo horizontes e enriquecendo a percepção de mundo, mas pode também ser apreendido de maneira tendenciosa. O mercado capitalista prioriza as veiculações que dão IBOPE, em detrimento de conteúdos educativos, muito embora se perceba que os conteúdos da televisão que se propõe não educativa predominam como tal, por seu alto poder de penetração, e, assim, influenciam a construção social da realidade em questões de hábito, consumo e atitude. Por sua vez, podemos obter nesses novos sistemas de tecnologias o acesso ilimitado a informações e direcionar nosso interesse aos conteúdos de qualidade. Vai depender das mudanças nas estruturas individuais e sociais.

Não se trata apenas do ato de informar. A comunicação é um processo de partilha, multidirecional, que possibilita a existência das relações interpessoais e dos seus desdobra- 
mentos. Assim sendo, o processo comunicativo consiste na passagem da esfera individual à esfera coletiva e se encontra no cerne das satisfações básicas, as necessidades de afeto, autoestima e realização, sendo essencial ao desenvolvimento do ser humano e presente em todas as construções de códigos gerados no seio dos grupos sociais. Para Bordenave (1998), o processo da comunicação é uma das formas que os homens utilizam para se relacionarem. Compreendemos a informação como um conjunto de elementos que se relacionam e se influenciam. Nesta pesquisa, tratamos de dois aspectos do processo comunicacional: o do ser humano e o da organização social. Desse modo, a comunicação sofre variações, constituindo-se nos comportamentos vividos comunicados e adaptados entre si. Cada grupo se identifica com seus grupos de pertencimento.

A comunicação tem as novas tecnologias como uma aliada no processo de produção, envio e recebimento de mensagens. Nos fios dessa atualidade, a história oral foi utilizada nesta pesquisa para aproximar o passado e o presente em perspectivas, acrescentando uma terceira dimensão: o futuro. Trançar essa história trouxe, à luz das considerações, definições que viabilizem um papel social importante para o homem rural, fundamentada na proposta de que o campo não é tão estático como se julga. Devemos, segundo Arroyo (1999. p. 14): "Termos consciência de que hoje onde há mais vida no sentido de movimento social, onde há mais inquietação é no campo".

Qualquer organização precisa selecionar suas prioridades e planejar o que se deseja transmitir e por meio da comunicação convencer em seu contexto. A transmissão adequada de uma mensagem é um dos fatores essenciais para o sucesso de um indivíduo, uma organização ou uma nação. Percebemos, também, que nessa construção social da realidade a percepção de criatividade na comunicação encontra apoio em Bordenave (1998, p. 82). Ele sugere que cabe aos intelectuais "articular as demandas já evidentes do povo para que os meios de comunicação e sua tecnologia respondam melhor aos anseios de autoexpressão, relacionamento, participação e prazer estético".

A educação deve se fazer crítica e libertadora, por meio dos canais de comunicação disponíveis, buscando conteúdos produtivos com características sólidas sem ser hermética e, a partir daí proporcionar oportunidade de ser utilizada na construção do conhecimento concreto, permeando a vida cotidiana da sociedade. Apreende-se o conhecimento como processo inacabado e, portanto, passível de modificações que visem à mobilidade social dos sujeitos. O conhecimento não é para ser guardado e sim socializado com as novas gerações.

É primordial na comunicação institucional a preocupação dos sujeitos com a transmissão dos dados oriundos da academia, geradas de suas pesquisas. A forma de comunicar suas pesquisas para um público leigo deve considerar não apenas a mensagem transmitida, mas, principalmente, a compreensão por parte desse público, de forma objetiva e clara no ato de comunicar. Nessa perspectiva, insere-se a necessidade de perceber a importância dos meios de comunicação de massa e seus conteúdos, tornando-se impossível pensar numa sociedade sem a informação que molda a vida cotidiana, individual, social e seus comportamentos. 
Nesse sentido, a socialização da informação científica para as comunidades rurais está relacionada quase sempre à sua inexistência. Há, no entanto, uma demanda em larga abrangência e variedade, cuja finalidade é reduzir o grau de incerteza que permeia a atividade agrícola e não agrícola de modo geral. As percepções construídas na vida cotidiana, entrelaçadas com o social e a comunicação do homem comum, atendem aos pressupostos de Calhoun (2012) quando afirma que vários são os aspectos na prática da comunicação, que o ato de comunicar contribui com experimentos, mas se encontra interligado mais profundamente com "as etnografias, pesquisas históricas, análises textuais e métodos cada vez mais visuais". Nas constituições sociais desse homem rural, percebemos a riqueza de conhecimento prático, de senso comum, sua cultura entrelaçada com a ruralidade, num mundo construído em cima de valores e pensamentos específicos, captando por meio da oralidade recheada de dialetos. Essa abordagem vem confirmar o papel da comunicação como prática social, onde os atos de comunicação e os recursos tecnológicos utilizados devem contribuir para a melhoria do padrão de vida e bem-estar dessa população.

Atualmente, quando pensamos em comunicação nos vêm, quase que automaticamente, computadores, internet e celulares multimídias. No entanto, a arte da comunicação já estava presente e acessível para o homem das cavernas por intermédio de sinais e gestos. Apesar de toda tecnologia, persiste a necessidade de um canal de comunicação direcionado para o homem rural, expondo a necessidade do letramento digital. Uma breve reflexão sobre a ativa transformação dos meios de comunicação de massa e a enérgica atuação dos seus usos nos apresenta as inúmeras possibilidades de inclusão das minorias. No entanto, apesar dos críticos que discordam dessa inclusão social através dos meios de comunicação de massa, não devemos ignorar que esses não se sobrepõem à pluralidade cultural numa coletividade atualizada, permanecendo inalteradas suas raízes históricas (INTERCOM, 2001). Essa percepção solicita que se lide com as novas tecnologias no processo de comunicação por meio de uma análise crítica do uso desses meios e nas dinâmicas inseridas nessas transformações através dos conteúdos, percebendo-as como parte dos processos sociais que impulsionam o homem enquanto ser social. É necessário reconhecer a educação como um processo transformador, com produção infindável de conhecimento, onde as Instituições de Ensino se colocam como mediadoras, contextualizando as realidades numa retroalimentação, apreendendo as mídias e seu uso em consonância com a comunicação em contexto social.

Mais que descartar a passividade do receptor, o educador deve colocá-lo como sujeito ativo, capaz de provocar mudanças no processo de ensino e aprendizagens. $\mathrm{O}$ educador deve se posicionar no mesmo nível horizontal dos sujeitos, uma via de mão dupla, um processo de realimentação, onde os educadores e educandos têm muito a aprender, pontuando o respeito e valorização do conhecimento prático e das experiências vividas.

Apreendemos a comunicação virtual como um espaço importante dentro da Instituição, conectada com a atualidade dos canais de comunicação, apropriando-se desses novos canais como nova modalidade no processo de comunicar, que se constituem como parceiros, numa realimentação constante, integrando os contextos educacionais e comuni- 
cacionais, que fazem parte da nova sociedade e atuam sobre a rotina de todos. No âmbito acadêmico não poderia ser diferente, uma vez que pensar em educação e comunicação significa reconhecer a influência dos meios de comunicação atuais, que alimentam o fluxo de informação nesse processo de socialização de informações. As instituições escolares, em qualquer nível devem abraçar a multiplicidade dos meios, ampliando a construção social da realidade, tornando-se mais interessante para os discentes, modificando sua maneira de interagir com os meios de comunicação, aderindo às novas tecnologias.

Apesar da era tecnológica e da sociedade rural encontrar-se em condições estruturais de acesso às mídias eletrônicas, há ainda a necessidade de um letramento digital para que possam desfrutar desses espaços de descobertas e de construção do conhecimento por meio das informações disponíveis. Defendemos a utilização das novas tecnologias no processo de comunicação e educação por intermédio de uma análise crítica do uso desses meios e nas dinâmicas inseridas nessas transformações através dos conteúdos, percebendo-as como parte dos processos sociais que impulsionam o homem enquanto ser social.

Trazemos a contribuição de Afonso que pontua o alcance do rádio, citando a tecnologia que agrega ao telefone celular outras funções, contextualizando com a arte de comunicar "porque o indivíduo vai com telefone celular, tudo tem rádio, ele fica com ele no bolso, o rádio ali bipado... cortando capim, ordenhando vaca, derrubando vaca, tudo bipado" e completa:

(...) existe o programa do meu amigo Gláucio Costa, rádio, 5 horas da manhã,
ele é forrozeiro que usa a linguagem do matuto rural, diz que eu vou comer um
cuscuz lá... (...) respondendo à pergunta de seu José Mariano do Sitio Mochila,
atendendo a pergunta de papiloma... (...) “estamos aqui com dr. (omitido) co-
mendo um cuscuz...vai sair um guisadinho daqui a pouco...enquanto isso ele
vai responder ... (risos) Rapaz... isso tem um poder de penetração espetacular...
espetacular... (...) não tem coisa melhor para a Universidade um elemento...
um veículo (...) Você chega em qualquer vacaria hoje, tem um rádio ligado,
e eles dizem...escutei o senhor hoje doutor.... Escutei você, viu? (...) eles já
conhecem... (...) não tem coisa melhor para a universidade um elemento, um
veículo (...)

Esse enfoque nos remete à folkcomunicação, processo ao qual a transmissão de informações de líderes de opinião alcança em determinada população. Esse processo nasce nos meios de comunicação de massa e por meio de "canais folk, ou seja, populares, e chegam a pessoas consideradas marginalizadas socialmente como as de um interior isolado, grupos urbanos de baixo poder aquisitivo e aqueles que são adeptos da contracultura" (INTERCON, 2013).

É necessário reconhecer a educação como um processo transformador, com produção infindável de conhecimento, onde as Instituições de Ensino se colocam como mediadoras, contextualizando as realidades numa retroalimentação, apreendendo as mídias e seu uso em consonância com a comunicação em contexto social. Os agentes da comunicação de qualquer Instituição educacional podem e devem ampliar horizontes para além dos muros 
escolares, reconhecendo que a sociedade encontra-se envolvida com a comunicação midiatizada, necessitando de um direcionamento para os conteúdos de qualidade.

É necessário o desenvolvimento de competências comunicacionais, por meio de modelos ecléticos de comunicação, onde instituição e público se sintam escutados, propondo sugestões de atuação, análises e reflexões, facilitando a tomada de consciência e promovendo a autoestima. Segundo Arroyo (1999, p. 29), por intermédio da educação entendemos o seu vínculo com as questões da saúde, cooperação, justiça e cidadania no terreno dos grandes valores da vida e da formação humana. Sugere ainda que uma educação participativa é aquela que "seja inclusiva, democrática, igualitária, que trate com respeito e dignidade as crianças, jovens e adultos no campo, que não aumente a exclusão dos que já são excluídos".

Um dos objetivos do Programa Momento Rural era a comunicação por meio de diálogos entre os diversos atores envolvidos. Uma comunicação eficaz e compreensiva. As instituições de ensino podem estimular a sociedade na reflexão acerca das condições de vida e as novas formas de acesso da população aos seus conhecimentos, tendo como alvo a sociedade não informada. A Universidade deve procurar canais de comunicação que associem sua imagem à promotora de encaminhamentos em torno dos problemas da sociedade. Devem se colocar a serviço do povo e construir uma relação de comunhão entre os homens, visando seu desenvolvimento social, mudando suas estruturas de reconhecimento, num intercâmbio de experiências. Nessa nova configuração de comunicação voltada para o social, as instituições de ensino devem perceber suas responsabilidades no papel de difundir o conhecimento produzido por intermédio de suas pesquisas, tecendo com as várias formas de comunicação, para estar em constante relação com outros homens, pronunciando o mundo.

A arte do diálogo, que não é um simples despejar de palavras, é ir ao encontro, gerando um clima de confiança e bem-estar, utilizando a empatia na busca do processo de sinergia e, nessa busca simultânea, consegue construir verdadeiras relações, com mais propriedade, causando impacto nos vários grupos sociais. É evidente que muitos fios foram necessários para a tecelagem dessa manta da comunicação, entrelaçados com a História Oral, numa construção da evidência científica. Torna-se necessário que, agora, os nós sejam amarrados com as considerações finais.

\section{CONSIDERaÇões Finais}

Como uma manta de muitos fios no tear imaginário, chegamos ao fim de sua urdidura e amarraremos os fios soltos, tecendo algumas considerações. Nessa tecelagem, a arte de comunicação e a riqueza da memória nos proporcionaram a construção do conhecimento do homem em sua essência. No amarrar dos fios, foi possível concluir que atingimos os nossos objetivos propostos nessa tecelagem da comunicação, buscando canais de comunicação direcionado ao homem rural, em tempos de novas mídias.

Compreendemos a comunicação no passado em perspectiva com a atualidade, em tempos de multimídias articulando pensamentos numa união de saberes, podendo construir 
conhecimentos para novas gerações. Foi possível perceber ao longo dessa tecelagem a socialização dos resultados das nossas pesquisas, visando mudanças sociais junto ao homem rural. Entre os múltiplos fios foi possível perceber que num intervalo de 20 anos, persiste a insuficiência de ações voltadas à disseminação de resultados, fato que gera descompasso entre os princípios que norteiam a UFRPE, enquanto instituição de educação pública, voltada aos problemas rurais e o que esse homem rural espera.

Nos fios dos meios de comunicação de massa, em especial, a televisão e o rádio, torna-se necessário que as instituições de ensino voltadas para a área rural se configurem como agente reflexivo e transformador, idealizando condições de estruturas produtivas com o objetivo de pronunciar as demandas dos seus públicos rurais. Que passe a entender o receptor com potencial para reelaborar produtos culturais veiculados, segundo o seu contexto produtivo e os seus próprios valores.

Por intermédio dos meios de Folkcomunicação, observa-se que o rádio aciona a difusão de informações visando à comunicação popular. Não é possível fazer comunicação popular tão-somente com aparelhos sofisticados, é necessário que se faça com homens, que se apropriam e se idealizam dentro de suas pluralidades culturais. Esse estilo de comunicação se presta ao dialeto simples ou rebuscado da cultura verificado em localidades específicas, "visto que há expressões que só podem ser compreendidas em determinados contextos", levando em conta sua natureza simbólica de significados (INTERCON, 2013).

Nessas construções sociais da realidade, podemos concluir que os processos comunicacionais devem servir ao propósito de colocar-se à disposição do diálogo e participação intercomunicativa. Apenas a imaginação é o limite para a utilização de recursos na comunicação, que poderá ser utilizada de modo adequado às diversas realidades do homem, com espírito fortalecido sob as asas do social, elemento essencial da construção do conhecimento, que considera o contexto histórico da sociedade e da região, entendendo o moderno como produção de ações na vida cotidiana do povo. A comunicação é, pois, um processo contínuo e permanente. Um educador humanista utiliza o poder da comunicação para transformação, respeitando valores e convicções, buscando a libertação pela educação (FREIRE, 2013).

Em relação aos avanços tecnológicos dos meios de comunicação, Thompson (1998) traça o perfil dessas transformações que ele chama de organização social e poder simbólico. Procura mostrar que o desenvolvimento dos meios de comunicação, desde a mais remota forma de impressão até as recentes comunicações eletrônicas, surge como parte integral da sociedade moderna. Para esse autor, essas transformações dos meios de comunicação se entrelaçam, de maneira complexa, com outros processos, de tal forma que, considerado em sua totalidade, constitui o que se chama "modernidade" em contextualização social. Complementando esse viés, Calhou (2012) afirma que dentro dessa modernidade a comunicação se interliga a múltiplas áreas, e que apesar do avanço da tecnologia ser a mais marcante, "os estudos mais criativos de mídia não se sustentam sozinhos, eles conectam a mídia com outras questões, tais como: as mudanças culturais, a desigualdade social e a estrutura organizacional". O universo simbólico das construções sociais da realidade abraça 
os indivíduos e a sociedade com a historicidade da vida cotidiana e toda a sua construção é realizada por meio das objetivações sociais onde o indivíduo se localiza.

A comunicação pode ser objeto da instituição, oferecendo à sociedade cidadania e qualidade de vida, desenvolvimento local, promoção de mudanças sociais e autossustentabilidade econômica e social das comunidades e municípios. Os resultados nos mostram que o panorama atual das tecnologias da informação podem contribuir e aliar novos formatos na arte de comunicar, socializando a riqueza de conhecimento construído na Instituição. Em princípio, o que se espera é que por meio da comunicação se construam percepções sólidas junto ao seu público em geral, e ao homem rural em particular, por intermédio de pesquisas transmutadas em linguagem que dialoguem com as realidades dos sujeitos, gerando assim tomadas de decisões em conjunto, organizando, orientando e mudando a vida cotidiana das pessoas. Nesse sentido, passa pela Comunicação Social a socialização das informações científicas com as comunidades rurais, tendo por objetivo transformar a realidade cristalizada desses indivíduos, influindo nas atitudes e ações, numa associação entre comunicação e educação.

Amarrando os nós e deixando um fio solto para que as instituições de ensino voltadas para a área rural, no papel de construtoras de saberes, possam buscar novos formatos de comunicação, que visem à socialização do conhecimento em todos os meios disponíveis, seja televisão, rádio ou internet, onde possa mediar o diálogo dos conteúdos numa realimentação das trocas desses saberes.

\section{REFERÊNCIAS}

ALBERTI, V. Manual de história oral, 3. ed. Rio de Janeiro: FGV, 2005.

ARROYO, M. G.; Fernandes, B. M. A educação básica e o movimento social do campo. Brasília, DF: Articulação Nacional por uma Educação Básica no Campo, 1999 (Coleção por uma educação básica do campo, n. 2).

BERGER, P. L.; LUCKMANN, T. A construção social da realidade: tratado da sociologia do conhecimento, 28. ed. Petrópolis: Vozes, 2008.

BORDEnAVE, J. E. D. Além dos Meios e Mensagens. Comunicação como sistema e ciência, 8. ed. Petrópolis: Vozes, 1998.

CALHOUN, C. Comunicação como ciência social (e mais). Intercon-RBCC, São Paulo, v. 35, n. 1, p. 277-310, jan./jun. 2012.

FREIRE, P. Extensão ou comunicação? 16. ed. Rio de Janeiro: Paz e Terra, 2013. . Pedagogia do Oprimido. Rio de Janeiro: Paz e Terra, 2005.

INTERCOM - Sociedade Brasileira de Estudos Interdisciplinares da Comunicação CONGRESSO BRASILEIRO DA COMUNICAÇÃO, 24, 2001, Campo Grande, MS. Disponí- 
vel em: <www.portcom.intercom.org.br>. Anais. Acesso em: 20 mar. 2015.

INTERCOM - Sociedade Brasileira de Estudos Interdisciplinares da Comunicação XVIII CONGRESSO DE CIÊNCIAS DA COMUNICAÇÃO NA REGIÃO SUDESTE - Bauru-SP - 03 a 05/07/2013. Acesso em: 30 out. 2017.

JOUTARD, P. Desafios à história oral do século XXI. In: ALBERTI, V.; FERNANDES, T. M.; FERREIRA, M. M. (Org.). História oral: desafios para o século XXI [on-line]. Rio de Janeiro: Fiocruz, 2000.

LE GOFF, J. História e memória. Campinas, SP: Editora da UNICAMP, 1990.

PORTELLI, A. Memória e diálogo: desafios da história oral para a ideologia do século XXI. In: FERREIRA, M. M.; FERNANDES, T. M.; ALBERTI, V. (Org.). História oral: desafios para o século XXI. Rio de Janeiro: Fiocruz, 2000.

. O que faz a história oral diferente. Projeto História, SP, n. 14, p. 25-39, 1997.

SILVA, J. S. Produção da informação impressa para produtores rurais da Paraíba: o caso do suplemento JP Rural (1993-1994), 1997, 192s. Dissertação (Mestrado em Administração Rural e Comunicação Rural) - Universidade Federal Rural de Pernambuco, Recife, 1997.

THOMPSON, P. R. A voz do passado: história oral, 2. ed. RJ: Paz e Terra, 1998.

Dados dos AUTORES:

\section{RAMOFly BicalHo}

Docente na UFRRJ - Universidade Federal Rural do Rio de Janeiro, Campus Seropédica. Lotado no Departamento de Educação do Campo, Movimentos Sociais e Diversidade. Docente na Licenciatura em Educação do Campo, no PPGEA - Programa de Pós-Graduação em Educação Agrícola e no PPGEduc - Programa de Pós-Graduação em Educação, Contextos Contemporâneos e Demandas Populares. Pós-Doutorando em Educação na Universidade Federal Fluminense - UFF. Título do Projeto: História da Educação do Campo e os Movimentos Sociais no Brasil: as ações do PROCAMPO na formação de educadores. Atuo com as seguintes temáticas: História da Educação do Campo e os Movimentos Sociais. Educação Popular e Educação de Jovens e Adultos.

\section{Edna Cherias}

Mestre em Educação pelo PPGEA - Programa de Pós-Graduação em Educação Agrícola. Técnica em Assuntos Educacionais na UFRPE - Universidade Federal Rural de Pernambuco.

Submetido em: 16-11-2016

Aceito em:6-2-2018 